\title{
Personalized System of Instruction (PSI) and Lesson Study (LS): a comparative analysis of two successful teaching methods
}

\author{
Sistema Personalizado de Instrução (SPI) e Estudo de Lição (EL): \\ uma análise comparativa de dois métodos de ensino bem sucedidos
}

\author{
Arthur Damião Médici ${ }^{1}$ \\ João dos Santos Carmo ${ }^{2}$
}

\begin{abstract}
Educational researchers are concerned with the investigation and improvement of teaching methods, and data obtained this study evidences their efficacy. The Personalized System of Instruction (PSI) and Lesson Study (LS) are two evidence-based effective teaching methods applied in varied disciplines in several countries with different theoretical backgrounds, procedures and evaluation strategies. In general, PSI research focuses on student development, lesson planning relies on an instructor, instructions are written, evaluation based on experimental manipulation, and shortcomings involve issues like student procrastination, excessive preparation and supervisor training time. LS research focuses on teacher and student development, instructions are varied, the assessment is based on a performance of the student, and teacher perception and shortcomings include excessive meeting time. This article suggests that both PSI and LS can benefit from the investigating implementation of each other's features.

Keywords: Teaching and Learning, Personalized System of Instruction, Lesson Study, Comparative Analysis.
\end{abstract}

RESUMO: Os pesquisadores educacionais estão preocupados com a investigação e aperfeiçoamento dos métodos de ensino e os dados obtidos evidenciam a sua eficácia. O Personalized System of Instruction (PSI) e Lesson Study (LS) são dois métodos de ensino efetivos baseados em evidências aplicados em disciplinas variadas em países com diferentes contextos teóricos, procedimentos e estratégias de avaliação. Em geral, a pesquisa do PSI concentra-se no desenvolvimento do aluno, o planejamento de lições depende de um instrutor, as instruções são escritas, a avaliação baseia-se em manipulação experimental e as deficiências envolvem problemas como a procrastinação dos alunos, a preparação excessiva e o tempo de treinamento do supervisor. A pesquisa do LS concentra-se no desenvolvimento do professor e do aluno, as instruções são variadas, a avaliação é baseada no desempenho do aluno e na percepção do professor e as deficiências incluem o excessivo tempo de reunião. Este artigo sugere que tanto PSI quanto LS, podem se beneficiar com a implementação investigativa dos recursos uns dos outros.

Palavras-chave: Ensino e aprendizagem, Sistema Personalizado de Instrução, Estudo de Lição, Análise Comparativa.

\section{INTRODUCTION}

The development of teaching technologies has been a research concern in different areas. One of the main contributions in Behavior Analysis to teaching technologies the Personalized System of Instruction - PSI as a product of Keller's work (KELLER, 1968;

\footnotetext{
${ }^{1}$ Master in Psychology from the Federal University of São Carlos and researcher of the National Institute of Science and Technology on Behavior, Cognition, and Teaching, E-mail: arthur.medici@gmail.com.

2 Doctor in Education from the Federal University of São Carlos, Department of Psychology, advisor professor of Graduate Program in Psychology and researcher of the National Institute of Science and Technology on Behavior, Cognition, and Teaching, E-mail: jcarmo@ufscar.br.
} 
MICHAEL 1996). It began with the teaching of Morse code and culminated in a method that identifies fundamental components of complex behavior, organizes them in a logical sequence and arranges conditions for students to achieve such goals at their own pace (KELLER, 1968; BOYCE; HINELINE, 2002).

Its applicability allowed its later use to teach a wide range of disciplines (ABBOT; FALSTROM, 1977; ZENCIUS; DAVIS; CUVO, 1990; CROSBY, 1984; CROSS; SEMB, 1975; DRAKE, 1998, FIKE et al., 2011, REISER, 1984, RAE; SAMUELS, 2011).

PSI have been investigated for many years. Schmitt (1998) argues that increased use of PSI in the 1970s was followed by a decrease in the 1980s and such decrease is related to the failure to teach behavioral approaches to faculty, the greater effort and time required to prepare PSI-related materials, professors' preference for the role of lecturer, and the hostility of administrators and another faculty to PSI. Researchers such as Lindslay (1992) and Sidman (2006) lament on the decay of PSI and the amount of resources and dedication devoted to it even though research has proved its effectiveness.

Another major and more current contribution to teaching technologies is Lesson Study (LS). It results from the works of Lewis (1992) and has been widely spread across Asian countries due to its favorable results in students' learning, its reflection on national and institutional test results (NORWICH; YLONEN, 2013; KILIÇ; DEMIR; ÜNAL, 2011) and its applications with the development of pedagogical content knowledge of student teachers (MATANLUK; JOHARI; MATANLUK; 2013; NORWICH; YLONEN, 2013, DEMIBURBAK, 2011; DUDLEY, 2013).

LS publications have increased since its first, in 2003, as evidenced in Figure 1.

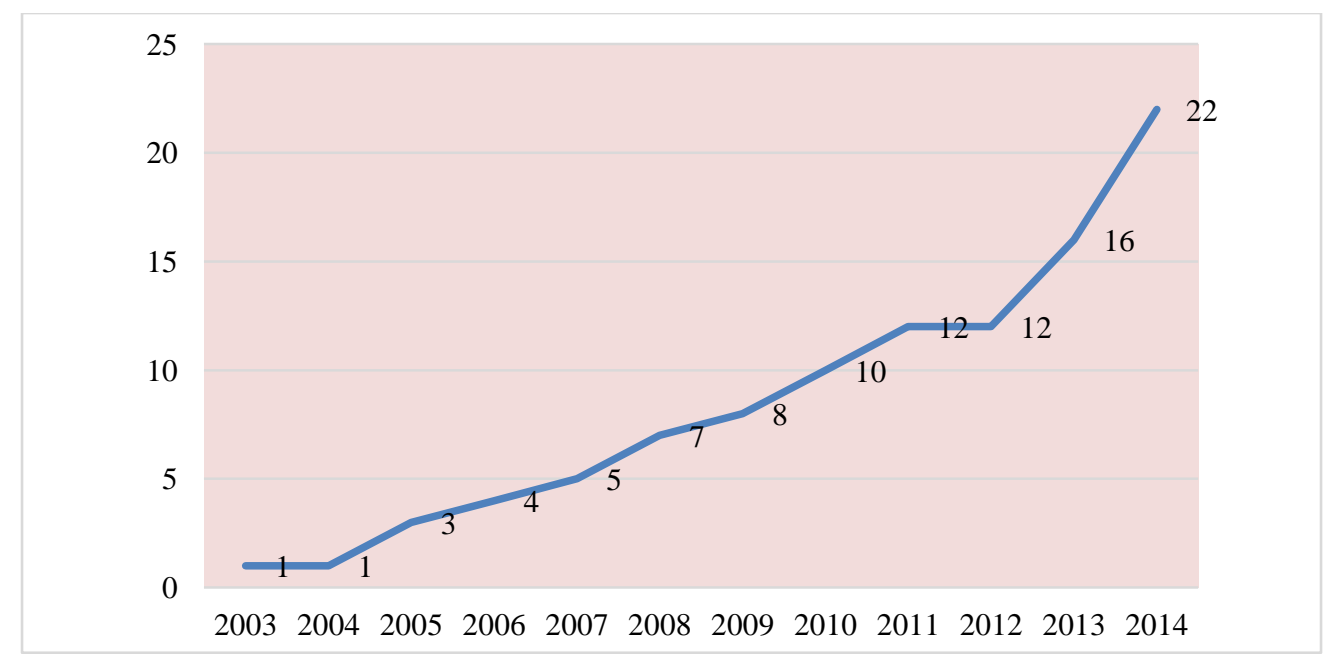

Figure 1. Cumulative representation of LS articles published on indexed peer-reviewed journals. Source: Chart prepared by authors.

On LS, lessons are planned, executed, analyzed and modified collaboratively (SIMS; WALSH, 2009). It has originally aided the teaching of elementary mathematics (NESUSIN et al., 2014; FERNANDEZ, 2010; PARKS, 2008) but later applied to other disciplines (DEMIRBULAK, 2011) due to its wide applicability. 
Since Lesson Study has shown favorable results to both student and teacher development, Western countries have shown interest in it (DUDLEY, 2013; FERNANDEZ; CANNON; CHOKSHI, 2003). According to bibliographic analysis, 22 studies regarding analysis and application of Lesson Study have been published in English indexed peerreviewed journals. They were realized in 9 countries, being the US and the UK the only western ones as shown in Figure 2.

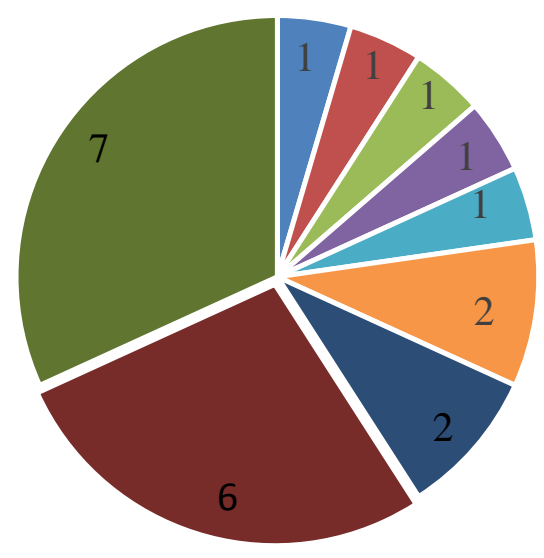

- China

- Hong Kong

Singapore

- Malasia

- Japan

United Kingdom

- Turkey

- Thailand

- United States

Figure 2. Countries in which LS studies were realized, according to the works analyzed. Source: Chart prepared by authors.

Scrutiny on PSI and LS allows the identification of many common features in spite of their different theoretical backgrounds; the present study aims to compare these two different teaching technologies according to what they propose to achieve, as well as the way they aid planning, execution, and assessment of lessons.

Both methods aim educational development as a long-term goal. Careful investigation and peer-reviewed publications evidence such concern.

Studies on PSI commonly investigate the effect of instruction on students' performance. They assess the effect of variables such as different types of instruction (RISER, 1984) the frequency of feedback (FARMER; LACHTER; BLAUSTEIN; COLE, 1972), frequency of testing (ABBOTT; FALSTROM, 1977) type of proctoring (GAYNOR; WOLKING, 1974), and the effect of personalized instruction on the performance of "at-risk" students (RAE; SAMUELS, 2011).

Assessment is based on quiz and test performance, which is commonly developed by the course instructor (ABBOTT; FALSTORM, 1977). Thus research results are based on data obtained by course application and do not emphasize the process of planning and analyzing a lesson - although such emphasis can be seen in studies conducted in Brazil after Keller's work at University of Brasilia (KIENEN; KUBO; BOTOMÉ, 2013; CORTEGOSO; COSER, 2011).

Research on LS, on the other hand commonly have dual purposes: honing students learning through carefully planned and assessed lessons (KILIÇ; DEMIR; ÜNAL, 
2011; DUDLEY, 2013), and providing teachers with tools and skills for teaching and testing hypotheses in the class. (MATANLUK; JOHARI; MATANLUK; 2013; DEMIBURBAK; 2011; INPRASITHA, 2014b; KANAUAN; INPRASITHA, 2014; SIMS ; WALSH, 2009). Teacher assessment is based on LS group video analyses and teachers' opinions (FERNANDEZ; CANNON; CHOKSHI, 2003; INPRASITHA; CHANGSRI, 2014; INPRASITHA, 2014; ISODA, 2010) evidencing emphasis on the process of planning and analyzing a lesson.

Fernandez (2010) argues that the microteaching process in Lesson Study provides teachers with important tools to improve pedagogical knowledge. In her study, after interviewing 18 prospective teachers and analyzing videos of LS group meetings, she discusses that teachers were better able to plan student-centered lessons, align lessons with overarching goals, select more efficient examples to be used in a lesson, make curricular decisions on when to introduce a certain concept and understand aspects of the instruction that were likely to cause confusion.

\section{METHODOLOGY}

The present study is a critical review of the literature dealing with SPI and LS. It is a bibliographical research with the consultation to electronic databases.

Initially, the following descriptors were identified: Lesson Study, Personalized System of Instruction, LS, PSI, and Evidence-Based Learning. Then these databases were accessed Science Direct, PsychArticles, and Web of Science. A search period was not delimited considering that the criterion used was the report of studies performed with LS and PSI. Theoretical-conceptual papers were used to describe the main characteristics of each method. Study reports were used to compare objectives, characteristics, convergences and other aspects present in each method. Thus, the fundamental criteria were theoretical-conceptual articles and research reports for both methods.

Initially, the texts were selected after reading the abstracts. Those abstracts that fulfilled the selection criteria were inserted in a spreadsheet, and the respective articles were read in their entirety.

On the next topic, the results of the search are presented, as well as the discussion of the same ones based on categories created from the conducted survey.

\section{RESULTS AND DISCUSSION}

\subsection{Lesson planning}

Both methods consider lesson planning a fundamental step that needs to be carefully executed, once a lesson has to assure a number of conditions in order to facilitate students' learning (KELLER, 1968; SIMS; WALSH, 2009; SAITO; ATENCIO, 2013) however, they have different approaches to how a lesson should be planned.

Both methods propose that lesson planning should begin with well-established 
goals based on curriculum needs and teaching must facilitate the achievement of such goals (ABBOTT; FALSTORM, 1977; SAITO; ATENCIO, 2013; DEMIRBULAK, 2011; DUDLEY, 2013, ISODA, 2010). However, due to their different theoretical backgrounds, they have a different understanding of the way goals should be described.

PSI states that goals are behaviors that students should be able to present at the end of a unit or course (FARMER; LACHTER; BLAUSTEIN; COLE,1972; CROSS; SEMB, 1975; CROSBY, 1984). For instance, Born and Davis (1974) compared the amount of study dedicated to finishing a PSI versus a lecture Psychology Course, and they propose that students should be able to "give examples" and "distinguish key concepts" as examples of course goals.

The planning of a PSI course normally relies on a teacher or professor known as the instructor. They are responsible for establishing goals according to what students must be able to do by the end of the course, identifying and sequencing students' skills necessary to the achievement of such goals, as well as planning and sequencing learning conditions able to evidence whether students achieve such goals. In addition, proctors and assistants aid the execution of the program, data collection, and student feedback. (KELLER, 1968).

LS, however, states that lesson planning - as well as any other step - should be a result of a collaboration between teachers working together as authors call "Lesson Study Groups" (SAITO; ATENCIO, 2013; SIMS; WALSH, 2009; INPRASITHA, 2014). Lessons are planned singularly as opposed to a group of lessons planned on PSI. According to Sims and Walsh (2009) "a single lesson contains many (if not all) of the critical components that teachers must consider to improve instruction".

Sims and Walsh (2009) also argue that collaboration has a major role in teacher development, for instance by helping pre-service teachers take students' perspective with the aid of more experienced teachers. In the study of Inprasitha (2014), teachers stated that the exchange of ideas favored their change of beliefs. As another example, Kanauan and Inprasitha (2014), while observing teachers' interaction in the process, concluded that teachers with different backgrounds had different contributions to the process.

Lesson Study also differs from PSI when it comes to describing goals. Some studies propose that lesson goals, besides involving students' problem-solving skills, should also be based on the type of students teachers wish to foster (FERNANDEZ; CANNON; $\mathrm{CHOKSHI}, 2003)$. The description of goals is varied, for instance, Puchner and Taylor (2006) report some examples of teacher-centered goals, such as “improving children's independent problem solving", "having all students be mentally and physically involved in [math] lessons, and creating an academic environment where students could be risk takers without fear of failuring". On the other hand, Silver et al. (2005) report a study case in which the goal was "finding multiple solutions to a problem", in which case, is student-centered. 


\subsection{Lesson execution}

Lesson execution is possibly the aspect in which methods differ the most. Execution of a PSI lesson commonly relies on written instructions (CROSS; SEMB, 1975). Students actively study the program and undergo a series of exercises, quizzes, and tests. Proctors are responsible for providing feedback to students Satisfactory scores on program tests allow access to supplementary material such as lectures and extra reading material, which are characterized as a motivational feature - not as the main component of the course, as opposed to traditional lecture methods (KELLER, 1968; MARTIN; PEAR; MARTIN, 2002b; BOYCE; HINELINE, 2002).

Students' achievement is assessed through test grades and mastery is required from students to provide them with more than one opportunity to achieve goals (KELLER, 1968; SCHMITT, 1998). Although Keller (1968) originally proposes that mastery should be demonstrated by $100 \%$ achievement, other studies have settled for lower achievements (FIKE et al. 2011). Johnston and O'Neill (1973) analyzed the effect of 4 different mastery criteria - i.e., $90 \%, 75 \%, 60 \%$, and in the criteria. They found that students on a "no-criteria" condition performed at a very poor performance compared to the other conditions. Better performing students were the ones in $90 \%$ criteria group.

One key component to achieving goals is proctored feedback, which has also raised research interest. Gaynor and Wolking (1974) for instance analyzed the effect of two types of proctoring: one performed by students who have previously mastered the course and another one by classmates. The second condition resulted in better students' performance indicating that proctoring might account for both Procter and proctor improvement. As another example, Martin, Pear, and Martin (2002a) assessed the quality of proctor feedback on a computer-aided system of instruction. The feedback of 33 student proctors was evaluated, and they identified 559 instances in which proctoring was appropriate - i.e., instances of proctoring (IOPs). They found that individual error rates - total errors as a percentage of total IOPS for a given proctor - ranged from $0 \%$ to $50 \%$.

The execution of a lesson in LS, on the other hand, commonly involve instructions for a group of students based on a single lesson planned collaboratively (SIMS; WALSH, 2009) as opposed to planning an entire course as it is the case of PSI. Teachers normally execute a lesson as a way of testing teaching hypotheses (DEMIRBULAK, 2011; DUDLEY, 2013). For instance, Fernandez, Cannon and Chockshi (2003) emphasizes four critical aspects of the concept "teacher as a researcher": "development of meaningful and testable hypotheses, the use of appropriate means for exploring these hypotheses, the reliance on evidence to judge the success of research endeavors, and the interest in generalizing research findings to other applicable contexts"

As previously presented, some of the goals established by Lesson Study are teacher-centered goals; however, assessment commonly takes students' performance into account. For instance, Kiliç, Demir, and Ünal (2011) assessed the scores of 4498 8th 
grade students in an international exam, as well as the practices of 146 mathematics teachers. They found that students' scores are positively correlated to teacher collaboration frequency in discussing teaching methods and planning a lesson.

\subsection{Lesson evaluation}

Both methods state that, once a lesson is executed and data have been collected, teachers and instructors are now able to analyze the effect of instructions on students. The effectiveness of PSI is typically assessed based on a comparison with traditional "lecture methods" and students' satisfaction. Many methods show higher student achievement on the PSI method (ABBOTT; FALSTROM, 1977; BORN; DAVIS, 1974; BORN; GLEDHILL; DAVIS, 1972; CROSBY, 1984; CROSS; SEMB, 1975; DRAKE, 1998; FIKE et al., 2011) whereas other studies show similar results in both methods but indicate one favorable aspect of PSI. Lacroix, McCall, and Fike (2014) showed that students had the same level of achievement in both courses but reported a higher preference for the PSI course. Drake (1988) had similar comparison results, but PSI course students betterretained information five months after the course.

To assess the effect of different arrangements, studies on PSI commonly present the results of experimental manipulations between groups, for instance, Abbot and Falstrom (1977) investigated if test frequency throughout a course interfered on student achievement. In studies 1 and 2, they compared student achievement in 2 situations: one PSI course as proposed by Keller (1968) and one Lecture course with only one midterm and one final exam. In studies 3 and 4, PSI was kept constant, and weekly testing was added in the Lecture course. Results show that student achievement was significantly higher on PSI when compared to traditional lecture methods, but it is the same when frequent testing is added.

As previously stated, LS bases lesson evaluation on students' grades and video analyses, but the perspective of teachers and students are also taken into account. For instance, Matanluk, Johari, and Matanluk (2013) asked 10 teachers and 60 students to rate sentences from 1 to 5 in a Likert Scale, being 1 strongly disagree and 5, strongly agree. Teachers rated LS process, and students rated lessons taught. The majority of students (50+) agreed that teaching is more attractive, more convincing and best understood; teachers are better prepared and more diligent, and students have better performances, and they are better prepared for exams.

\subsection{Shortcomings}

Student and teacher development have been investigated at length due to their complexity. Shortcomings are constantly mentioned in such studies since they provide the opportunity for further research, and their understanding might make teaching and learning more rewarding processes. 
Through PSI courses, for instance, instructors constantly deal with students' procrastination due to its individualized feature (ROSS; MCBEAN, 1995, BORN; DAVIS, 1974). Researchers also found that extensive preparation of instructional materials and proctor coaching are also difficulties to be overcome (BOYCE; HINELINE, 2002). Born and Davis (1974) manifested a concern that PSI courses might be more expansive to the institution; thus they investigated if the amount of time students spend engaging in PSI activities was significantly higher when compared to traditional lecture courses. They found that, although PSI students spent about $50 \%$ more time studying in the student center, lecture students spent such time difference attending lectures.

Lesson Study, for being a collaborative method that deals with planning single lessons, faces difficulties such as the need for excessive teachers' labor due to extensive planning and discussions (LEE, 2008), increased school budget requirements due to extensive hours teachers work to plan, execute and evaluate lessons (NORWICH; YLONEN, 2013), difficulty in keeping focus on all the relevant aspects of a lesson (FERNANDEZ; CANNON; CHOKSHI, 2003) and excessive feedback to student teachers due to the presence of many experienced observers (TSUI; LAW, 2007).

Excessive preparation time is a common concern in both methods. Also, time and dedication required to prepare student teachers for LS can be compared to time and dedication required to prepare proctors on PSI. Although this excessive dedication is reported as a problem for some participants, it is considered essential for the success of both methods. For this reason, evidence suggests that schools set aside resources to prepare teachers and proctors as a crucial step for students' success.

\section{FINAL CONSIDERATIONS}

The current study provides a further understanding of the main features of teaching methods that have been researched through more than ten years. Some of the most important are well-established learning goals, careful lesson planning, assessment of students, staff, and classes, and knowledge of shortcomings to be overcome through the process. Moreover, it indicates that in spite of different theoretical backgrounds, successful teaching methods have many convergences and will eventually have shortcomings. In order to hone teaching resources and better deal with shortcomings, the topics covered in the current work deserve careful attention and investigation.

Teaching methods can benefit from features presented here, and that includes benefits that PSI and LS may have when their characteristics are compared. For instance, much can be achieved if PSI incorporated collaborative lesson planning and evaluation. Besides, LS may also benefit if a group of lessons was planned - as opposed to individual ones - to be better aligned with overarching goals. Further research is required to analyze the effect of novel procedures in existing methods. 


\section{REFERENCE}

ABBOTT, R. D.; FALSTROM, P. Frequent testing and personalized systems of instruction. Contemporary Educational Psychology, v. 2, n. 3, p. 251-257, 1977.

BORN, D. G.; DAVIS, M. L. Amount and distribution of study in a personalized instruction course and in a lecture course. Journal of Applied Behavior Analysis, v. 7, n.3, p. 365375. 1974.

BORN, D. G.; GLEDHILL, S. M.; DAVIS, M. L. Examination performance in lecture-discussion and personalized instruction courses. Journal of Applied Behavior Analysis, v. 5, n. 1, p. 33-43, 1972.

BOYCE, T. E.; HINELINE, P. N. Interteaching: A strategy for enhancing the userfriendliness of behavioral arrangements in the college classroom. Behavior Analyst, v. 25, n. 2, p. 215-226, 2002.

CAVEY, L. O.; BERENSON, S. B. Learning to teach high school mathematics: Patterns of growth in understanding right triangle trigonometry during lesson plan study. The Journal of Mathematical Behavior, v. 24, n. 2, p. 171-190. 2005.

CORTEGOSO, A. L.; COSER, D. S. Elaboração de Programas de Ensino: material autoinstrutivo. São Carlos: Edufscar, 2011.

CROSBY, L. G. Experiences with the Personalized System of Instruction (PSI) to teach elementary accounting. Journal of Accounting Education, v. 2, n.1, p. 139-143, 1984.

CROSS, M. Z.; SEMB, G. A personalized university course in nutrition. Journal of Nutrition Education, v. 7, n. 4, p. 149-151, 1975.

DEMIRBULAK, D. Training English language student teachers to become teacherresearchers. Procedia - Social and Behavioral Sciences, v. 30, p. 491-496, 2011.

DRAKE, M. A. A comparison of two teaching methods in an introductory college nutrition course: lecture vs. personalized system of instruction. Journal of Nutrition Education, v. 20, n.1, p. 11-14, 1988.

DUDLEY, P. Teacher learning in Lesson Study: What interaction-level discourse analysis revealed about how teachers utilized imagination, tacit knowledge of teaching and fresh evidence of pupils learning, to develop practice knowledge and so enhance their pupils' learning. Teaching and Teacher Education, v. 34, p. 107-121, 2013.

FARMER, J. LACHTER, G. D.; BLAUSTEIN, J. J. et al. The role of proctoring in personalized instruction. Journal of Applied Behavior Analysis, v. 5, n. 4, p. 401-404, 1972.

FERNANDEZ, C.; CANNON, J.; CHOKSHI, S. A US-Japan lesson study collaboration reveals critical lenses for examining practice. Teaching and Teacher Education, v. 19, n.2, p. 171-185, 2003. 
FERNANDEZ, M. L. Investigating how and what prospective teachers learn through microteaching lesson study. Teaching and Teacher Education, v. 26. n. 2, p. 351-362, 2010.

FIKE, D. S.; McCALL, K. L.; ESTES, F. G. et al. Promoting minority student learning gains in a prescription practice course. Currents in Pharmacy Teaching and Learning, v. 3. n.1, p. 17-22, 2011.

GAYNOR, J.; WOLKING, W. D. The effectiveness of currently enrolled student proctors in an undergraduate special education course. Journal of Applied Behavior Analysis, v. 7, n. 2, p. 263-269, 1974.

INPRASITHA, M.; CHANGSRI, N. Teachers' Beliefs about Teaching Practices in the Context of Lesson Study and Open Approach. Procedia - Social and Behavioral Sciences, v. 116, p. 4637-4642, 2014.

INPRASITHA, N. Perceptions on Professional Development of Supervisors in the Nonproject and Project Schools Using Lesson Study. Procedia - Social and Behavioral Sciences, v. 116, p. 2069-2073, 2014.

INTAROS, P.; INPRASITHA, M.; SRISAWADI, N. Students' problem solving strategies in problem solving-mathematics Classroom. Procedia - Social and Behavioral Sciences, v. 116, p. 4119-4123, 2014.

ISODA, M. Lesson study: problem solving approaches in mathematics education as a Japanese experience. Procedia - Social and Behavioral Sciences, v. 8, p. 17-27, 2010.

JOHNSTON, J. M.; O'NEILL, G. The analysis of performance criteria defining course grades as a determinant of college student academic performance. Journal of Applied Behavior Analysis, v. 6, n. 2, p. 261-268, 1973.

KANAUAN, W.; INPRASITHA, N. Collaboration between Inservice Teachers and Student Intern in Thai Lesson Study. Procedia - Social and Behavioral Sciences, v. 116, p. 2832, 2014.

KELLER, F. S. "Good-bye, teacher...". Journal of Applied Behavior Analysis, v. 1, n. 1, p. 79-89, 1968.

KIENEN, N.; KUBO, O. M.; BOTOMÉ, S. P. Ensino programado e programação de condições para o desenvolvimento de comportamentos: alguns aspectos no desenvolvimento de um campo de atuação do psicólogo. Acta Comportamentalia, v. 21, n. 4, p. 481-494, 2013.

KILIÇ, S.; DEMIR, I.; ÜNAL, H. Teachers Co-learning through Mutual Collaboration and Students' Mathematics Performance in TIMSS 2007. Procedia - Social and Behavioral Sciences, v. 15, p. 3258-3262, 2011.

LACROIX, M.; MCCALL, K. L.; FIKE, D. S. The Keller personalized system of instruction in a pharmacy calculations course: A randomized trial. Currents in Pharmacy Teaching 
and Learning, v. 6, n. 3, p. 348-352, 2014.

LEE, J. F. A Hong Kong case of lesson study - Benefits and concerns. Teaching and Teacher Education, v. 24, n. 5, p. 1115-1124, 2008.

MARTIN, T. L.; PEAR, J. J.; MARTIN, G. L. Analysis of proctor marking accuracy in a computer-aided personalized system of instruction course. Journal of Applied Behavior Analysis, v. 35, n. 3, p. 309-312, 2002a.

. Feedback and its effectiveness in a computer-aided personalized system of instruction course. Journal of Applied Behavior Analysis, v. 35, n. 4, p. 427-430, 2002 b.

MATANLUK, K.; JOHARI, K.; MATANLUK, O. The Perception of Teachers and Students toward Lesson Study Implementation at Rural School of Sabah: A Pilot Study. Procedia - Social and Behavioral Sciences, v. 90. p. 245-250, 2013.

MICHAEL, J. Fred S. Keller (1899-1996): Introduction. The Behavior Analyst, v. 19, n. 1, p. 3-5, 1996.

NESUSIN, N.; INTRARAKHAMHAENG, P.; SUPADOL, P. et al. Development of lesson plans by the lesson study approach for the 6th grade students in social study subject based on open approach innovation. Procedia - Social and Behavioral Sciences. v. 116, p. 1411-1415, 2014.

NORWICH, B. YLONEN, A. Design based research to develop the teaching of pupils with moderate learning difficulties (MLD): evaluating lesson study in terms of pupil, teacher and school outcomes. Teaching and Teacher Education, v. 34, p. 162-173, 2013.

PARKS, A. N. Messy learning: Preservice teachers' lesson-study conversations about mathematics and students. Teaching and Teacher Education, v. 24, n. 5, p. 12001216, 2008.

PUCHNER, L. D.; TAYLOR, A. R. Lesson study, collaboration and teacher efficacy: Stories from two school-based math lesson study groups. Teaching and Teacher Education, v. 22, n. 7, p. 922-934, 2006.

RAE, A.; SAMUELS, P. Web-based Personalised System of Instruction: An effective approach for diverse cohorts with virtual learning environments? Computers \& Education, v. 57, n. 4, p. 2423-2431, 2011.

REISER, R. A. Reducing student procrastination in a personalized system of instruction course. Educational Communication and Technology Journal, v. 32, n. 1, p. 41-49, 1984.

ROSS, L. L.; McBEAN, D. A comparison of pacing contingencies in classes using a personalized system of instruction. Journal of Applied Behavior Analysis, v. 28, n. 1, p. 8788, 1995.

SAITO, E.; ATENCIO, M. A conceptual discussion of lesson study from a micro-political 
perspective: implications for teacher development and pupil learning. Teaching and Teacher Education, v. 31, p. 87-95, 2013.

SCHMITT, D. R. The Introductory class in higher education: Some old problems and new considerations. The Behavior Analyst, v. 21, n.2, p. 281-288, 1998.

SIDMAN, M. Fred S. Keller, a generalized conditioned reinforcer. The Behavior Analyst, v. 29, n. 2, p. 235-242, 2006.

SILVER, E. A.; GHOUSSEINI, H.; GOSEN, D. et al. Moving from rhetoric to praxis: Issues faced by teachers in having students consider multiple solutions for problems in the mathematics classroom. The Journal of Mathematical Behavior, v. 24, n. 3, p. 287301, 2005.

SIMS, L; WALSH, D. Lesson study with preservice teachers: Lessons from lessons. Teaching and Teacher Education, v. 25, n. 5, p. 724-733, 2009.

THINWIANGTHONG, S.; INPRASITHA, M. Pre-and In-service Teachers' Role to Improve the Teaching and Learning Mathematics. Procedia - Social and Behavioral Sciences, v. 116, p. 1940-1944, 2014.

TSUI, A. M. B; LAW, D. Y. K. Learning as boundary-crossing in school-university partnership. Teaching and Teacher Education, v. 23, n. 8, p. 1289-1301, 2007.

ZENCIUS, A. H.; DAVIS, P. K.; CUVO, A. J. A personalized system of instruction for teaching checking account skills to adults with mild disabilities. Journal of Applied Behavior Analysis, v. 23, n. 2, p. 245-252, 1990.

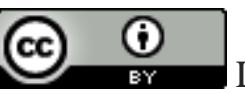

License information: This is an open-access article distributed under the terms of the Creative Commons Attribution License, which permits unrestricted use, distribution, and reproduction in any medium, provided the original work is properly cited.

Article received on August 29, 2017.

Accepted on January 20, 2018. 